\title{
The Development of Peace Counseling Model (PCM): Strategy of School Counselor to Reduce Students' Aggressive Behavior
}

\author{
Wahyu Nanda Eka Saputra ${ }^{1 *}$, Yulia Ayriza ${ }^{2}$, Irvan Budhi Handaka ${ }^{1}$, Ediyanto Ediyanto $^{3}$ \\ ${ }^{1}$ Department of Guidance and Counseling, Faculty of Teacher Training and Education, Universitas Ahmad Dahlan, \\ Pramuka Street No. 42, Yogyakarta, Special Region of Yogyakarta, Indonesia 55161 \\ ${ }^{2}$ Department of Guidance and Counseling, Faculty of Education, Universitas Negeri Yogyakarta, \\ Colombo Street No. 1, Sleman, Special Region of Yogyakarta, Indonesia 55281 \\ ${ }^{3}$ Graduate School for International Development and Cooperation, Hiroshima University, 1 Chome-3-2, Higashihiroshima, \\ Kagamiyama, Japan 739-8511 \\ *corresponding author, e-mail: wahyu.saputra@bk.uad.ac.id
}

Article received: April 15 $5^{\text {th }} 2019$; revised: July 23 ${ }^{\text {rd }} 2019$; accepted: November $2^{\text {nd }} 2019$

\begin{abstract}
This study aimed to develop a counseling model to reduce students' aggressive behavior, namely Peace Counseling Model (PCM). This counseling model uses the basic theory of peace education that is specifically implemented in counseling. This study adapted the research and development model formulated by Borg \& Gall. The research used quantitative descriptive analysis. There was a strong agreement between experts and practitioners on the feasibility of the product being developed to be implemented by school counselor. The results of this study should be a reference to further research to test the effectiveness of PCM to reduce students' aggressive behavior.
\end{abstract}

Keywords: aggressive behavior; peace; peace counseling

Abstrak: Penelitian ini bertujuan mengembangkan sebuah model konseling untuk mereduksi perilaku agresif siswa, yaitu PCM. PCM dikembangkan menggunakan teori dasar pendidikan kedamaian yang secara spesifik terimplementasikan dalam konseling. Penelitian ini mengadaptasi model penelitian dan pengembangkan yang dirumuskan oleh Borg \& Gall. Teknik analisis data menggunakan analisis deskriptif kuantitatif. Ahli dan praktisi yang dilibatkan dalam proses pengembangan PCM menyatakan bahwa model konseling ini layak untuk diimplementasikan oleh konselor sekolah. Hasil penelitian ini seyogyanya dapat menjadi rujukan bagi peneliti selanjutnya agar menguji keefektifan PCM untuk mereduksi perilaku agresif siswa.

Kata kunci: perilaku agresif; kedamaian; konseling kedamaian

\section{INTRODUCTION}

One of the leaders of world peace, Mahatma Gandhi, once stated that to achieve peace, we must start with children (Johnson \& Johnson, 2010; Khan, 2011). His statement shows that the building of peace of mind in children is one of the significant efforts that should be carried out; one of the attempts is through education (Hilker, 2011; Smith, 2010; Spaaij \& Jeanes, 2013). Building peace of mind through an education process is called peace education (Zembylas \& Bekerman, 2013). The building of peace of mind in children can support the success of education in minimizing conflict and acts of violence occurring, especially in schools.

Peace can be divided into two forms, namely, negative peace and positive peace (Galtung \& Fischer, 2013). Negative peace is the emergence of a peaceful situation that is only limited to the absence of war. In contrast to negative peace, positive peace is a condition of ultimate peace. Positive peace is the peace

How to cite: Saputra, W. N. E., Ayriza, Y., Handaka, I. B., \& Ediyanto, E. (2019). Development of Peace Counseling Model (PCM): Strategy of School Counselor to Reduce Students'Aggressive Behavior. Jurnal Kajian Bimbingan dan Konseling, 4(4), 134-142. https:/doi.org/10.17977/ um001v4i42019p134 
that is not only when there is no war, but also the absence of social injustice, impoverishment, and even humiliation of human dignity. Positive peace can be achieved through long cooperative processes and one of them through the educational process (Hilker, 2011; Smith, 2010). Educational efforts that are passed through must involve various components so that the educational goal of achieving positive peace is achieved.

In Indonesia, positive peace is something that all Indonesians want to achieve (Capie, 2016; Hutabarat, 2018). The statement was stated in the opening of the 1945 Constitution. This case proves that the aspirations of the Indonesian people to participate in maintaining order and world peace have been declared from the beginning. Therefore, peace of mind in every Indonesian citizen, including students who are studying in school, needs to be encouraged. One of the parties who have strong competence to help students develop the peace of mind is the school counselor through guidance and counseling services, even if examined in more detail, the school counselor does not specifically have a program in building a culture of peace in students.

Building peace of mind in children through education turns out to be inversely proportional to the problems that occur in students in schools, especially vocational high schools. Vocational high school students are in the adolescent development phase. This phase is the crisis phase and in a transition phase from children to adults. In the adolescent phase, there is also a search for self-identity that might trigger various problems. Understanding adolescents about their identity can encourage adolescents to behave better and is not easily influenced by the environment to prevent adolescents from negative selfidentity (Sumiati, 2012). The research results showed that the finding phase for adolescent identity was significantly correlated to juvenile delinquency (Paramitha, 2013). Aggressive as one form of juvenile delinquency is physical or verbal behavior that has the purpose of intentionally hurting others (Myers \& Smith, 2015). Aggressive behavior arises to respond to threats (according to perception or really exist) originating from other individuals or groups outside the group (MacLaren, Best, \& Bigney, 2010).

Several studies have shown that aggressive behavior is one of the problems that need the attention of many parties. A study conducted at a junior high school in Yogyakarta showed that $1 \%$ of students had very high aggressiveness; $13 \%$ of them had high aggressiveness; $37 \%$ of them had moderate aggressiveness; $43 \%$ of them had low aggressiveness; and $6 \%$ of them had very low aggressiveness (Alhadi, Purwadi, Muyana, Saputra, \& Supriyanto, 2018). Subjects in the research conducted at the junior high school level specifically had different levels of development from vocational students but still had similarities, namely the subjects were in the adolescent phase. When viewed from gender, there was no difference in the level of aggressiveness between female students and male students (Saputra, Hanifah, \& Widagdo, 2017).

The conditions described in the previous paragraph indicate that there is still a gap between expectation and reality in the field. If the problem of aggressiveness among students is not immediately resolved, a culture of bullying for example, will have a negative impact on the comfort of students in school (Nickerson, Singleton, Schnurr, \& Collen, 2014) and students' involvement in learning (Cornell, Shukla, \& Konold, 2016; Einarsen, Skogstad, Rørvik, Lande, \& Nielsen, 2018; Mehta, Cornell, Fan, $\&$ Gregory, 2013). The culture of bullying that occurs among students is one of the predictors of a high level of dropout in students (Cornell, Gregory, Huang, \& Fan, 2013). The school climate which is not conducive due to the emergence of various aggressive behaviors also ultimately has an impact on the decline in academic achievement of students (Kosciw, Palmer, Kull, \& Greytak, 2013; Milam, FurrHolden, \& Leaf, 2010; O’Malley, Voight, Renshaw, \& Eklund, 2015; Wang et al., 2014).

One effort to build a conducive climate in schools is by building peace of mind in students through education, commonly known as the concept of peace education (Harris, 2010; Harris \& Morrison, 2012; Salomon \& Cairns, 2011). The essence of peace is in the human mind (Anand, 2014). Therefore, the school counselor should take extra efforts to build peace in every student's mind at school. Peace education, based on the study results, can be applied in Indonesia (Saputra, 2016; Saputra, Widiasari, \& Dina, 2016).

Specifically, peace education implemented to reduce aggressive behavior is conducted in counseling settings through peace counseling. Peace counseling is developed using basic theories of peace education that can encourage the awakening of awareness about non-violence, anti-justice, anti-environmental 
concerns, and other values of peace (Galtung \& Fischer, 2013; Navarro-Castro \& Nario-Galace, 2010). Peace education arises to respond to the many problems of violence, such as physical and non-physical wars resulting in casualties (Navarro-Castro \& Nario-Galace, 2010).

Peace counseling is also compatible to be implemented in Indonesia (Saputra \& Handaka, 2017b). One of the goals of peace counseling is to develop students 'peace of mind' so that counseling becomes students' mediators to reduce their aggressive behavior. Until now, the concept of peace counseling has not been specifically developed, especially in Indonesia. Peace counseling is also not yet popular and has no form, so this is the basis for this development research. Specifically, this study aimed to develop PCM that can be used to help students reduce their aggressive behavior.

\section{METHOD}

This research used research and development design with the Borg \& Gall pattern. This research and development was limited to three stages of development, namely: (1) identification of the level of aggressive behavior that forms the basis of PCM development, (2) preparation of a hypothetical draft PCM product to reduce aggressive behavior, and (3) an assessment by one expert and one practitioners to assess the feasibility of the PCM that has been developed (Gall, Borg, \& Gall, 2003).

In detail, the activities carried out at the three stages of research and development were: (1) identifying the level of students' aggressive behavior by distributing instruments in the form of a scale of aggressive behavior to students at Muhammadiyah Vocational High School of Yogyakarta, especially class XI. The scale of aggressive behavior consists of 38 items, which after testing the validity, was declared valid. The reliability test results showed a coefficient of 0.823 categorized as having a high level of reliability (Saputra \& Handaka, 2017a). The population involved in this study amounted to 298 students. This study applied stratified random sampling, and the samples were 160 students; (2) Preparing an initial draft of PCM to reduce the students' aggressive behavior. This draft was prepared by looking at the characteristics of students' aggressive behavior problems and also based on the concept of peace education theory; (3) carrying out a feasibility assessment by experts and practitioners, namely a department of guidance and counseling lecturer from Universitas Ahmad Dahlan with innovation expertise in guidance and counseling and a school counselors that have the expertise to provide counseling services to promote behavioral change from counselees, especially aggressive behavior. Experts and practitioners involved were asked to assess by filling out the product feasibility assessment sheet developed. The expert and practitioner assessment sheets consist of three aspects, namely a general description of the product, product usability, and product accuracy.

This study employed descriptive qualitative techniques with percentages. This data analysis was carried out to describe the level of aggressive behavior of students in Muhammadiyah Vocational High School of Yogyakarta so that it would be known the percentage of students who had aggressive behavior in the very high, high, moderate, low, and very low categories. In addition, the analysis of the inter-rater reliability (IRR) coefficient of Cohen's Kappa describes the level of feasibility of the product being developed, namely PCM, to reduce the students' aggressive behavior.

\section{RESULTS}

Based on the formulation of the problem and the purpose of the study, the research results describe three main parts. First, the data on the level of aggressive behavior of vocational school students in Yogyakarta were divided into several categories, namely: very high, high, moderate, low, and very low. Second, a hypothetical draft of the product was presented, namely, PCM, to reduce the students' aggressive behavior. Third, the product feasibility data was presented, namely, PCM, to reduce the students' aggressive behavior.

\section{Students' Aggressive Behavior Level}

Identification of vocational high school students' aggressive behavior level in Yogyakarta was conducted by using an aggressive behavior scale (Saputra \& Handaka, 2017a) that was then analyzed statistically and descriptively by using SPSS. The analysis results are presented in Table 1. Based on the analysis results presented in Table 1., the score range was obtained for categorization of aggressive 
Table 1. Descriptive Statistics

\begin{tabular}{lccccccc}
\hline & N & Range & Minimum & Maximum & Sum & Mean & $\begin{array}{c}\text { Std. } \\
\text { Deviation }\end{array}$ \\
\hline VAR00001 & 160 & 76 & 39 & 115 & 12596 & 78.7250 & 13.33834 \\
Valid N (listwise) & 160 & & & & & & \\
\hline
\end{tabular}

Table 2. Score Range of Categorization of Aggressive Behavior Scale

\begin{tabular}{lc}
\hline Category & Score Range \\
\hline Very low & $58.74-39$ \\
Low & $58.75-72.04$ \\
Moderate & $72.05-85.34$ \\
High & $85.35-98.62$ \\
Very high & $98.63-115$ \\
\hline
\end{tabular}

Tabel 3. Aggressive Behavior Level

\begin{tabular}{lcc}
\hline Category & The number & Percentage \\
\hline Very high & 7 & $5 \%$ \\
High & 42 & $26 \%$ \\
Moderate & 64 & $40 \%$ \\
Low & 34 & $21 \%$ \\
Very low & 13 & $8 \%$ \\
\hline
\end{tabular}

behavior scale, as shown in Table 2. Based on Table 2., the percentage of aggressive behavior level is presented in Table 3. Table 1 displays that the number of samples involved to fill the scale of aggressive behavior was 160 students in Muhammadiyah Vocational High School of Yogyakarta. The highest score of the level of aggressive behavior was 115, and the lowest score of the level of aggressive behavior was 39, with a standard deviation of 13.33834. Furthermore, in table 2, the range of score data in the category of aggressive behavior in the very low category was 58.74-39; low category of 58.75-72.04; medium category of $72.05-85.34$; high category of 85.35-98.62; and the very high category was $98.63-$ 115. Based on table 3, it is known that the data on the level of aggressive behavior of students in Muhammadiyah Vocational High School of Yogyakarta: 5\% of them were in the very high category; $26 \%$ of them were in the high category; $40 \%$ of them were in the moderate category; $21 \%$ of them were in the low category; and $8 \%$ of them were in the very low category (Saputra \& Handaka, 2018).

\section{Draft of PCM Hypotetic to Reduce Students' Aggressive Behavior}

PCM was developed based on the concept of peace education to reduce conflicts that lead to peace of heart, both intrapersonal and interpersonal. The peace counseling model developed included the following stages: (1) the rational peace counseling model, (2) exploring the root of the problem of violence, (3) reflection of violent phenomena from various perspectives, (4) teaching finding alternative violent behavior, (5) looking for different forms of violence and eliminate them, and (6) evaluation and follow-up. The peace counseling model stages were carried out for six counseling session with a duration of about 35 minutes per session. The stages were undertaken to help students reduce their aggressive behavior. The six steps of peace counseling are illustrated in Figure 1.

\section{Feasibility of PCM to Reduce Students' Aggressive Behavior}

The product developed, namely PCM to reduce aggressive behavior, was assessed as feasible by one expert and one practitioner. The results of the product feasibility assessment by experts and practitioners are presented in table 4 . The assessment of the feasibility of a product in the form of a PCM to reduce aggressive behavior was carried out by experts who were lecturers as well as researchers 


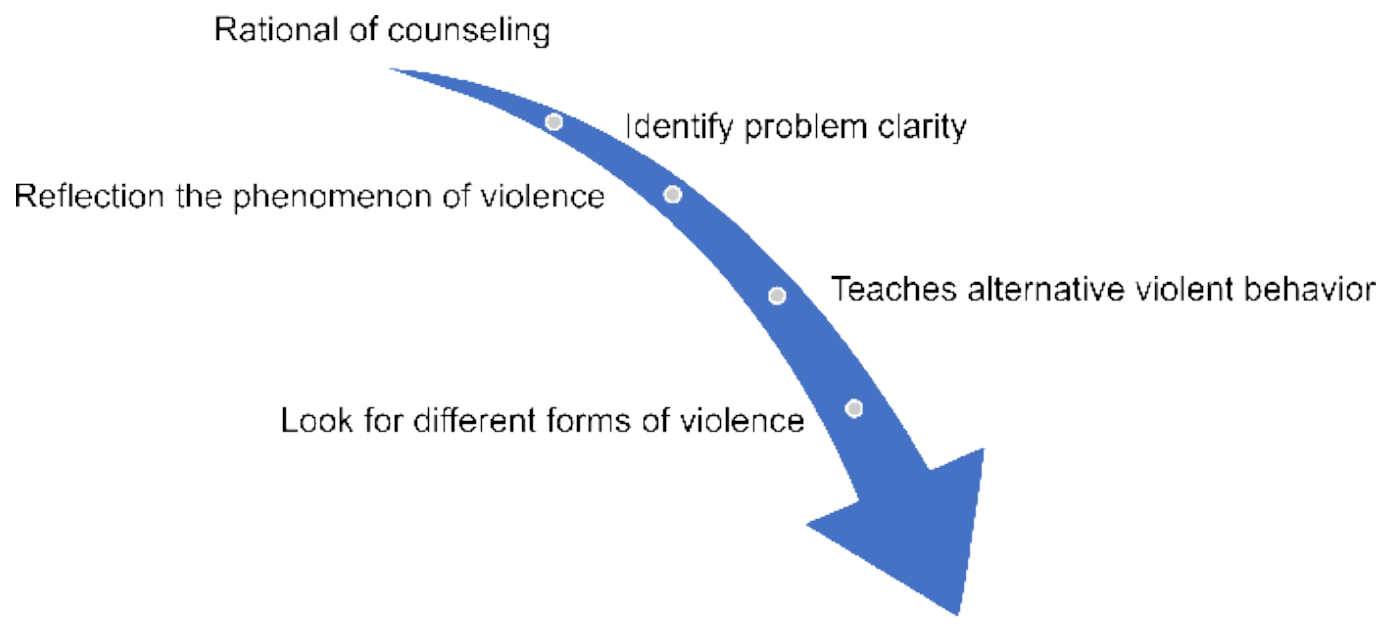

Evaluate and follow up

\section{Figure 1. Stages of PCM}

Table 4. Results of Expert and Practitioner's Assessment to Feasibility of PCM

\begin{tabular}{|c|c|c|}
\hline No & Aspects & Mean of Score \\
\hline 1 & General description of PCM & 3.1 \\
\hline 2 & The accuracy of PCM to reduce aggressive behavior & 3 \\
\hline \multirow[t]{2}{*}{3} & The benefits of PCM for a counselor to reduce students' aggressive behavior & 3.6 \\
\hline & Mean & 3.2 \\
\hline
\end{tabular}

Table 5. Analysis of Cohens's Kappa Coefficient

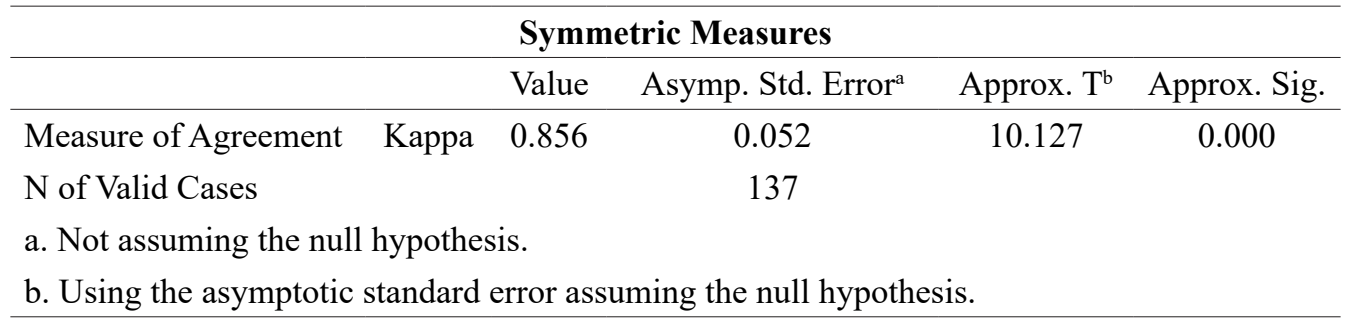

who studied innovation of guidance and counseling. The product was also assessed by practitioners who worked as professional school counselors in vocational high schools. The average rating given by experts and practitioners to PCM to reduce aggressive behavior was 3.2. After being assessed by experts and practitioners, the feasibility of PCM to reduce aggressive behavior was identified by using the interrater reliability (IRR) of Cohen's Kappa coefficient on the agreement of the assessment undertaken by these experts and practitioners. The results of the analysis using SPSS software are presented in Table 5.

Based on table 5, it is known that the IRR, the Cohen's Kappa coefficient shows the inter-rater reliability of $\mathrm{K}=0.856$. These coefficients are included in the strong category. The value of Cohen's Kappa coefficient means that there was a strong agreement between experts and practitioners about the feasibility of the product being developed. Asymp Std. Errors indicate standardized measurement errors, which means that the small magnitude of this coefficient indicates the more reliable measurement results were made. The significance value of 0.000 was smaller than the significance level used by $5 \%$ $(0.000<0.05)$, which means that there was a significant agreement between experts and practitioners at a significance level of $5 \%$ for the product being developed. 


\section{DISCUSSION}

The first findings in this study indicated that the data on the level of aggressive behavior of vocational students in Yogyakarta was 5\% of the students were in very high level of aggressive category; $26 \%$ of the students were in the high category; $40 \%$ of them were in the moderate category; $21 \%$ of them were in a low category, and $8 \%$ of them were in the very low category (Saputra \& Handaka, 2018). The results of this study showed that aggressive behavior was still a problem that has not been alleviated to the maximum and could affect students' self-actualization in learning at school. One of the effects of aggressive behavior that arose among students was the poor climate of the students' school and the effect on students' achievement (Mehta et al., 2013; Milam et al., 2010; O’Malley et al., 2015; Wang et al., 2014).

This research was supported by other studies that identified the level of aggressive behavior of students in Yogyakarta, which concluded that $1 \%$ of students had very high aggressiveness; $13 \%$ of them had high aggressiveness, $37 \%$ of them had moderate aggressiveness, $43 \%$ of them had low aggressiveness, and $6 \%$ of them had very low aggressiveness (Alhadi et al., 2018). However, that study identified the level of aggressive behavior of junior high school students in Yogyakarta with a cluster random sampling technique, while this study investigated the level of aggressive behavior of vocational students in Yogyakarta with stratified random sampling technique.

Other research on the profile of students' aggressive behavior conducted based on aspects of physically hurting others, hurting others verbally, and damaging or destroying property showed that $35.32 \%$ of students physically hurt others, $41.30 \%$ of them verbally hurt others, and $30.42 \%$ of them destroyed or damaged goods (Hidayat, Yusri, \& Ilyas, 2013). However, that study was limited to 94 class XI students of Public Senior High School 5 Padang, while in this study involved all students in Muhammadiyah Vocational High School of Yogyakarta with a total sample of 160 students taken by stratified random sampling technique.

The first research findings that described the data on the level of aggressive behavior of students in Muhammadiyah Vocational High School of Yogyakarta, became the basis for the development of a hypothetical PCM draft to reduce students' aggressive behavior. This product was developed with the roots of the peace education theory, which, in essence, seeks to create an essential peace, that is positive peace (Cremin \& Bevington, 2017; Fitz-Gibbon, 2010; Shields \& Rissler, 2016). Positive peace actually attempts to oppose the concept of negative peace by providing resistance to physical and psychological violence that leads to the emergence of aggressive behavior and conflict, and education of peace tries to rise to meet that challenge (Fitz-Gibbon, 2010).

PCM applied in counseling services had six main stages. The first stage was a rational PCM. At this stage, the counselor explained why aggressive behavior needs to be reduced, and one of his efforts was by using PCM. The second stage was exploring the root of the problem of violence. At this stage, the counselor seeks to explore the location and root of the problem of aggressive behavior by students. The third stage was the reflection of the phenomenon of violence. At this third stage, the counselor explored the forms of aggressive behavior based on the counselee's perspective. The fourth stage was to teach looking for alternatives to violent behavior. At this fourth stage, the counselor educated and provided examples of counselees to find alternatives to aggressive behavior. The fifth stage was looking for different forms of violence. At this fifth stage, the counselor facilitated the counselee to find a form of behavior which was different from what was usually done (behaving aggressively). The sixth stage was evaluation and follow-up. At this sixth stage, the counselor strived to identify the internalized values in the counselee and plans for further meetings (Saputra \& Handaka, 2018a).

Furthermore, the third finding from this study showed that there was a strong agreement between experts and practitioners regarding the feasibility of the product being developed, namely PCM, which could be applied by school counselors to reduce students' aggressive behavior. The emergence of this product can be an opportunity for counselors to be more proactive in helping the counselee to reduced their aggressive behavior.

The findings of this study were supported by other studies which stated that sustainable peacebuilding through educational efforts could be used to promote anti-violence schools (Bickmore, 2011). That study used a qualitative approach that had a high subjectivity from researchers, while this study employed a quantitative approach with more objective results. In addition, the emphasis of Bickmore's (2011) research on peacebuilding was still limited to education efforts in general, not 
yet conical in its implementation in counseling sessions. Peacebuilding, through counseling efforts, provided a great opportunity for counselors to directly intervene changes in students' behavior and not only at the cognitive level (mind).

Other research supporting this research reported that peace education programs could help students promote their empathy. That research was limited to the implementation of peace education in general in developing students' empathy. In addition, this research was limited to the development of students' empathy and had not yet led directly to real behavior, especially reducing aggressive behavior, although if empathy is traced based on previous studies, it is related to aggressive behavior (de Wied, Gispen-de Wied, \& van Boxtel, 2010; Eisenberg, Eggum, \& Di Giunta, 2010; Van der Graaff, Branje, De Wied, $\&$ Meeus, 2012). Based on these studies, the higher students' empathy level, the lower the aggressive behavior that arose. Conversely, the lower the students' empathy, the higher aggressive behavior that appeared in students.

Efforts to implement peace education through counseling settings (or what we call PCM) are not without obstacles. This condition is similar to a study in Kenya, which showed that the implementation of peace education had obstacles, including these efforts, which could not be done in all subjects and the emergence of proper coordination among school personnel (Mary, 2016). Such problems certainly also had the potential to arise in Indonesia in the implementation of PCM in schools. This condition certainly had a negative impact on the effectiveness of the implementation of peace education.

Research that developed PCM to decrease aggressive behavior had several limitations. First, this study used a research and development design that only reached the feasibility of testing a PCM tangible product to reduce aggressive behavior. This research has not yet reached the stage of testing the effectiveness of the product being developed, so the level of product effectiveness has not yet been identified empirically. The second limitation in this study was that the product produced was still restricted to the peace counseling model in general and was not linked to local wisdom at the place where the research took place. Local wisdom has a significant meaning in this peace counseling model, primarily to expedite the counseling process undertaken. The assumption, students will be able to easily accept certain information if the information has an element of cultural similarity with students.

\section{CONCLUSION}

Aggressive behavior is a problem that is still the responsibility of many parties. Various forms of aggressive behavior appear and have an impact on the emergence of perceptions of the school climate that are not conducive to students. This perception will be related to the level of students' academic achievement. One effort that needs to be done is that the counselor applies a form of counseling model to build a peace of mindset in students. The counseling model developed to develop this peace of mindset is called PCM. Based on the feasibility assessment, it can be concluded that there was a significant agreement between experts and practitioners that PCM is appropriate to be used in reducing aggressive behavior. This research recommends further research to test the effectiveness of PCM to reduce aggressive behavior and also try to integrate it with local wisdom.

\section{ACKNOWLEDGEMENT}

We want to thank Kementerian Riset Teknologi dan Pendidikan Tinggi (Ministry of Research Technology and Higher Education) that has funded this research, and Universitas Ahmad Dahlan that has provided opportunity and facilities to conduct this research successfully.

\section{REFERENCES}

Alhadi, S., Purwadi, P., Muyana, S., Saputra, W. N. E., \& Supriyanto, A. (2018). Agresivitas Siswa SMP di Yogyakarta. Jurnal Fokus Konseling, 4(1), 93-99.

Anand, S. (2014). The Contemporary Issues and Significance of Peace Education in India. International Journal of Research in Humanities, Arts and Literature, 2(10), 47-54.

Bickmore, K. (2011). Policies and Programming for Safer Schools: Are "Anti-bullying” Approaches Impeding Education for Peacebuilding? Educational Policy, 25(4), 648-687. 
Capie, D. (2016). Indonesia As An Emerging Peacekeeping Power: Norm Revisionist or Pragmatic Provider? Contemporary Southeast Asia, 1-27.

Cornell, D., Gregory, A., Huang, F., \& Fan, X. (2013). Perceived Prevalence of Teasing and Bullying Predicts High School Dropout Rates. Journal of Educational Psychology, 105(1), 138.

Cornell, D., Shukla, K., \& Konold, T. R. (2016). Authoritative School Climate and Student Academic Engagement, Grades, and Aspirations in Middle and High Schools. AERA Open, 2(2), 2332858416633184.

Cremin, H., \& Bevington, T. (2017). Positive Peace in Schools: Tackling Conflict and Creating A Culture of Peace in The Classroom. Routledge.

de Wied, M., Gispen-de Wied, C., \& van Boxtel, A. (2010). Empathy Dysfunction in Children and Adolescents with Disruptive Behavior Disorders. European Journal of Pharmacology, 626(1), 97-103.

Einarsen, S., Skogstad, A., Rørvik, E., Lande, Å. B., \& Nielsen, M. B. (2018). Climate for Conflict Management, Exposure to Workplace Bullying and Work Engagement: A Moderated Mediation Analysis. The International Journal of Human Resource Management, 29(3), 549-570.

Eisenberg, N., Eggum, N. D., \& Di Giunta, L. (2010). Empathy-Related Responding: Associations with Prosocial Behavior, Aggression, and Intergroup Relations. Social Issues and Policy Review, 4(1), 143-180.

Fitz-Gibbon, A. (2010). Positive Peace: Reflections on Peace Education, Nonviolence, and Social Change.

Gall, M. D., Borg, W. R., \& Gall, J. (2003). Educational Research, An Introduction. Sixth Edition, Longman. New York.

Galtung, J., \& Fischer, D. (2013). Positive and Negative Peace. In Johan Galtung (pp. 173-178). Springer.

Harris, I. (2010). History of Peace Education. Handbook on Peace Education, 11-20.

Harris, I. M., \& Morrison, M. L. (2012). Peace Education. McFarland.

Hidayat, H., Yusri, Y., \& Ilyas, A. (2013). Profil Siswa Agresif dan Peranan Guru BK. Konselor, 2(2).

Hilker, L. M. (2011). The Role of Education in Driving Conflict and Building Peace: The Case of Rwanda. Prospects, 41(2), 267-282.

Hutabarat, L. F. (2018). Diplomasi Indonesia dalam Misi Pemeliharaan Perdamaian PBB. Jurnal Pertahanan \& Bela Negara, 6(2).

Johnson, D. W., \& Johnson, R. T. (2010). 16 Peace Education in the Classroom: Creating Effective Peace Education Programs.

Khan, Y. (2011). Performing Peace: Gandhi's Assassination As A Critical Moment in The Consolidation of The Nehruvian State. Modern Asian Studies, 45(1), 57-80.

Kosciw, J. G., Palmer, N. A., Kull, R. M., \& Greytak, E. A. (2013). The Effect of Negative School Climate on Academic Outcomes for LGBT Youth and The Role of In-school Supports. Journal of School Violence, 12(1), 45-63.

MacLaren, V. V., Best, L. A., \& Bigney, E. E. (2010). Aggression-Hostility Predicts Direction of Defensive Responses to Human Threat Scenarios. Personality and Individual Differences, 49(2), 142-147.

Mary, A. (2016). Effectiveness of Peace Education Programmes in Secondary Schools: A Case Study of Kisumu Municipality, Kenya. International Journal of Liberal Arts and Social Science, 4(2), 29-30.

Mehta, S. B., Cornell, D., Fan, X., \& Gregory, A. (2013). Bullying Climate and School Engagement in NinthGrade Students. Journal of School Health, 83(1), 45-52.

Milam, A. J., Furr-Holden, C. D. M., \& Leaf, P. J. (2010). Perceived School and Neighborhood Safety, Neighborhood Violence and Academic Achievement in Urban School Children. The Urban Review, 42(5), 458-467.

Myers, D. G., \& Smith, S. M. (2015). Exploring Social Psychology. New York, NY.

Navarro-Castro, L., \& Nario-Galace, J. (2010). Peace Education: A Pathway to The Culture of Peace. Center for Peace Education, Miriam College.

Nickerson, A. B., Singleton, D., Schnurr, B., \& Collen, M. H. (2014). Perceptions of School Climate As A Function of Bullying Involvement. Journal of Applied School Psychology, 30(2), 157-181.

O’Malley, M., Voight, A., Renshaw, T. L., \& Eklund, K. (2015). School Climate, Family Structure, and Academic Achievement: A Study of Moderation Effects. School Psychology Quarterly, 30(1), 142.

Paramitha, D. A. (2013). Status Identitas Remaja akhir: Hubungannya dengan Gaya Pengasuhan Orangtua dan Tingkat Kenakalan Remaja. Character: Jurnal Penelitian Psikologi, 1(2).

Salomon, G., \& Cairns, E. (2011). Handbook on Peace Education. Psychology Press.

Saputra, W. N. E. (2016). Pendidikan Kedamaian: Peluang Penerapan pada Pendidikan Tingkat Dasar di Indonesia. Jurnal CARE (Children Advisory Research and Education), 3(3), 88-94. 
Saputra, W. N. E., \& Handaka, I. B. (2017a). Analisis Validitas dan Reliabilitas Skala Perilaku Agresi. Seminar Nasional Bimbingan Konseling Universitas Ahmad Dahlan, 2.

Saputra, W. N. E., \& Handaka, I. B. (2017b). Konseling Kedamaian: Strategi Konselor untuk Mereduksi Perilaku Agresi Remaja. In Prosiding Seminar Nasional Pendidikan Pancasila Dan Kewarganegaraan III.

Saputra, W. N. E., \& Handaka, I. B. (2018a). Model Konseling Kedamaian untuk Mereduksi Perilaku Agresi Siswa. Yogyakarta: K-Media.

Saputra, W. N. E., \& Handaka, I. B. (2018b). Perilaku Agresi pada Siswa SMK di Yogyakarta. Jurnal Fokus Konseling, 4(1), 1-8.

Saputra, W. N. E., Hanifah, N., \& Widagdo, D. N. (2017). Perbedaan Tingkat Perilaku Agresi Berdasarkan Jenis Kelamin pada Siswa Sekolah Menengah Kejuruan Kota Yogyakarta. Jurnal Kajian Bimbingan dan Konseling, 2(4), 142-147.

Saputra, W., Widiasari, S., \& Dina, D. (2016). Peace Education: Islamic Perspective. Proceeding 1st International Conference on Islamic Education.

Shields, P. M., \& Rissler, G. (2016). Positive Peace: Exploring its Roots and Potential for Public Administration. Global Virtue Ethics Review, 7(3).

Smith, A. (2010). The Influence of Education on Conflict and Peace Building, Background Paper Prepared for The Education for All Global Monitoring Report 2011 The Hidden Crisis: Armed Conflict and Education, Paris: UNESCO.

Spaaij, R., \& Jeanes, R. (2013). Education for Social Change? A Freirean Critique of Sport for Development and Peace. Physical Education and Sport Pedagogy, 18(4), 442-457.

Sumiati, E. (2012). Pengetahuan dan Sikap Remaja Tentang Identitas Diri Remaja pada Siswa SMA Kartika I-2 Medan. Jurnal Keperawatan Holistik, 1(1).

Van der Graaff, J., Branje, S., De Wied, M., \& Meeus, W. (2012). The Moderating Role of Empathy in The Association Between Parental Support and Adolescent Aggressive and Delinquent Behavior. Aggressive Behavior, 38(5), 368-377.

Wang, W., Vaillancourt, T., Brittain, H. L., McDougall, P., Krygsman, A., Smith, D., ... Hymel, S. (2014). School Climate, Peer Victimization, and Academic Achievement: Results From A Multi-Informant Study. School Psychology Quarterly, 29(3), 360.

Zembylas, M., \& Bekerman, Z. (2013). Peace Education in The Present: Dismantling and Reconstructing Some Fundamental Theoretical Premises. Journal of Peace Education, 10(2), 197-214. 